\title{
Colonial Sinews of Postcolonial Espionage - India and the Making of Ghana's External Intelligence Agency, 1958-61
}

\section{Avinash Paliwal}

To cite this article: Avinash Paliwal (2021): Colonial Sinews of Postcolonial Espionage - India and the Making of Ghana's External Intelligence Agency, 1958-61, The International History Review, DOI: $10.1080 / 07075332.2021 .1888768$

To link to this article: https://doi.org/10.1080/07075332.2021.1888768

\section{(C) 2021 The Author(s). Published by Informa UK Limited, trading as Taylor \& Francis Group}

\section{曲 Published online: 22 Feb 2021.}

Submit your article to this journal

III Article views: 518

Q View related articles

View Crossmark data $\nearrow$ 


\title{
Colonial Sinews of Postcolonial Espionage - India and the Making of Ghana's External Intelligence Agency, 1958-61
}

\author{
Avinash Paliwal \\ Department of Politics and International Studies, SOAS University of London, London, UK
}

\begin{abstract}
Based on untapped Indian archives, this article details how Delhi built Accra's security service in 1958-61. Keen to reduce its dependency on the outgoing British colonial administration, Ghana sought India's support when both the Cold War rivalry and the Afro-Asian Solidarity were at a peak. In doing so, Ghana inherited a similar set of problems affecting Indian intelligence, which in itself was supported by the British i.e. resorting to colonial policing methods, lack of legislative oversight, and a recruitment system based on partisan loyalties instead of professionalism. The Foreign Service Research Bureau (external intelligence) and the Special Branch (domestic intelligence) effectively secured Ghana's first prime minister and then president Kwame Nkrumah from real and perceived adversaries. But their methods of functioning fed his authoritarian appetite -ultimately leading to an unceremonious ouster- during a highly turbulent phase in Ghanaian history. The first and only time India helped create, and unofficially lead, another country's intelligence service, this history sheds light on India and Ghana's approach towards intelligence in the aftermath of independence.
\end{abstract}

\section{KEYWORDS}

Decolonisation; Intelligence; India; Ghana; Postcolonial

\section{Introduction}

How to distance Ghana's security services from the British, dominated Kwame Nkrumah's mind on Christmas Eve of 1956. Already Prime Minister of the Gold Coast since 1952, and soon to become president of Africa's first decolonised country, Nkrumah's Convention People's Party (CPP) pushed radical nationalist and pan-Africanist ideas since its creation in 1949. ${ }^{1}$ Full and immediate transfer of power to Ghanaians was crucial for the CPP, and this required a visible shift away from the outgoing colonial power for the future republic. That the CPP had severe, often violent, differences with domestic opposition groups, especially the United Gold Coast Convention (UGCC), afforded urgency to the need for indigenising Ghana's security services under Nkrumah. ${ }^{2}$ The problem was: how to create such an institution given Ghana's severe shortage of expertise on security, and in the light of Nkrumah's desire of seeking pan-African leadership that was grounded in Cold War neutralism? The impending exodus of British officials and Accra's simultaneously troubled relations with both London and Moscow limited Nkrumah's options. The answer, for him, lay in India. 
Deeply influenced by Jawaharlal Nehru's writings and leadership, on January 03, 1957, Nkrumah wrote a letter to the Indian Prime Minister. ${ }^{3}$ A leader of the Non-Aligned Movement who personified the 'Bandung spirit' of Afro-Asian solidarity, Nehru's support seemed appropriate. ${ }^{4}$ After detailing Ghana's administrative arrangements that will come into effect after independence, he requested India to create a 'Code and Cypher Section' to secure Ghana's secret communications. ${ }^{5}$ Nehru responded positively and sent a note to Nkrumah via India's acting commissioner in Accra detailing how Delhi dealt with the problem when it became independent. But, instead of sending Indian cypher experts to Ghana, he invited Ghanaian officers to Delhi. Nehru argued that the object of having a cypher is that 'it cannot be broken into by other governments' and for this reason, it would be easier for a Ghanaian officer 'to understand and grasp a system which is working than for some theoretical information to be given about it'. ${ }^{6}$

Not just the 'Cypher and Codes Section', India created -and led- Africa's first postcolonial external intelligence service, the Foreign Service Research Bureau (FSRB). Encouraged by Nehru's response, and after informal consultations between his advisor Daniel Chapman and the then Director of India's Intelligence Bureau (DIB) Bhola Nath Mullik, Nkrumah made a formal request in October 1957 for India to create Ghana's External Intelligence Service. ${ }^{7}$ This shift from a small cypher section to the creation of a security service was rooted in Ghana's shortage of technical experts and public servants. The situation was so dire that in December 1957 Nkrumah spoke of sending an 'SOS to Mr. Nehru' and his advisors informed the Indian high commissioner: 'unless India comes forward to help in a big way Ghana would have to stop all development activities'. 8 Especially on the intelligence front, Nkrumah confided to Nehru during their meeting in London at the Commonwealth Prime Minister's Conference in July 1957, that Ghana had 'no trained staff' and would 'greatly appreciate' if India would loan the services of an intelligence expert for a year.'

Curiously, Nkrumah wanted an Indian official to be the 'new head of the Service' in the first instance and 'lay down the foundation of the organisation'. ${ }^{10}$ India accepted Nkrumah's request for most part but refused overt leadership of Ghana's security service on Nehru's insistence. ${ }^{11}$ The FSRB became a potent arm of independent Ghana's security apparatus in addition to the Ghanaian national police and defence services. But, soon after its creation, the FSRB along with the policy special branch became a tool for suppressing dissent. ${ }^{12}$ Increased regional and international pushback against Ghana, deepening domestic fissures after Nkrumah's decision to remain president-for-life in 1964 (but also before), and a series of failed assassination attempts gave the president reason to forcibly detain opponents. ${ }^{13}$ In such conditions, the structures created and supported by India ended up affording immense operational powers, unchecked and unaccounted for, to Ghana's security services. So much so that military leaders with support from civilian intelligence and police services ended up ousting Nkrumah in a coup in $1966 .{ }^{14}$ Such skewed civil-military relations -in favour of civilians in India and the military in Ghana- raises questions about continuity and change in intelligence structures during the colonial and postcolonial period. ${ }^{15}$

Based on untapped Indian archives, this article, to begin with, demonstrates that postcolonial India's intelligence institutions, though re-created to an extent, continued along colonial policing pathways. This was visible in the Intelligence Bureau's (IB) domestic operations, and in India's intelligence cooperation with other postcolonial states, such as Ghana. Second, India's support to Ghana in the intelligence sector complicates the picture of seamless south-south postcolonial solidarities. Often assumed to have flowed naturally through shared experiences of colonial rule, such postcolonial solidarities were riddled with tensions. India's support for the creation of Ghana's intelligence institutions fit its image of a 'global peacemaker' and an ally of anti-colonial movements the world over, especially in Africa. ${ }^{16}$ But its continuing reliance on London in the intelligence sector, and Accra's diversification of external support in the security sector (including from Pakistan, Australia, and the UK), shows how despite recognition of collaborative ventures such as these, Asian and African countries struggled to cut the cord with colonial powers and develop strong south-south relationships anew in the security sector. Third, there is a clear intersection between colonial and postcolonial intelligence practices, modalities, and ideologies 
shaping the conduct and doctrine of intelligence gathering. This is visible in the institutional structures of intelligence gathering in both India and Ghana.

This article is divided into four parts. The first section unpacks India's approach towards intelligence after independence. It highlights how India's new leaders navigated from being the targets of, to leading the IB. Nehru's relationship with the IB and Mullik, plus his role as a critical consumer of intelligence, deeply impacted Indian intelligence. Keen to 'decolonise' institutions that it inherited from the colonial regime, India struggled to define and implement such a process in the security sector. In practice, Indian intelligence leaders viewed their partnership with Britain (and the US) critical for operational and training reasons, especially as the colonial foundations (organisational and legal) of these institutions were largely untouched. ${ }^{17}$ Ironically, Ghana, which sought India's support in lieu of Britain, received much of what Delhi inherited from London. The second section dives into Mullik's conceptualisation of Ghana's security service. His ideas mark continuity between colonial and postcolonial security practices, and left Ghana's intelligence services facing similar contradictions that afflicted India. Contradictions that effectively secured Nkrumah from real and perceived adversaries, but also fed his authoritarian appetite -ultimately leading to an unceremonious ouster. ${ }^{18}$

The third section demonstrates how Indian officers in Ghana approached their assignment. Whereas Nehru viewed it as an opportunity to strengthen India's non-aligned credentials, Mullik used it to strengthen the IB's capabilities and expose his officers to foreign postings. Support for Ghana itself was a secondary motivation for Indian intelligence professionals. This shows how two countries -one in Asia and the other in Africa- collaborated to buttress state capacity based on common political agendas of decolonisation and Afro-Asian unity during the Cold War. Yet, the urgency to secure their hard-won independence made both India, and by corollary Ghana, to adopt policing architecture and intelligence practices introduced during the colonial period. The concluding section offers analysis of continuity and change in India and Ghana's intelligence structures and practices. It argues that the use of intelligence for statecraft remained largely the same during the colonial and postcolonial periods in South Asia and West Africa. Despite moving beyond the Cold War binaries and attempts at decolonisation, India and Ghana retained the colonial policing core both out of postcolonial necessity and political convenience.

\section{India's postcolonial intelligence: domestic pressures, international opportunities}

India faced acute security pressures at independence. ${ }^{19}$ Not only were hostilities with Pakistan rife, the internal security situation too was precarious. Widespread communal violence was coupled with struggle for accession of princely states such as Hyderabad and Junagadh. Communist activity was on the rise, linguistic divisions were simmering, and the Naga insurgency had broken out in the Northeast. ${ }^{20}$ A combination of reduced British officers and division of resources between India and Pakistan during partition severely limited India's capacity to deal with these threats. ${ }^{21}$ As British officials noted in 1948, 'the Government of India realises that if they are going to hold India together, they have got to be strong, and they are therefore concentrating on building up their Armed Forces and Police'. ${ }^{22}$ Despite their desire for distance from the British, to address these limitations, Delhi rationalised in favour of continuing British support. Air Marshal Thomas Elmhirst led the air force, General Roy Bucher was the army chief, and Admiral Edward Parry was the navy chief. The decision to become part of the Commonwealth enabled the stationing of an overt security liaison officer (SLO) in Delhi who cooperated with the IB. ${ }^{23}$ In Elmhirst's view, India's former policy of 'driving the British out of India' was being reversed in practice, even if the rhetoric of decolonisation was accentuated to avoid 'loss of face'. ${ }^{24}$ But relative to the police, the intelligence agencies were hard hit.

Communal violence following independence ensured that India was acutely aware of the need to reinvigorate intelligence. ${ }^{25}$ In a letter to provincial premiers (future chief ministers) in 
November 1947, Nehru asserted the importance of developing intelligence both at the provincial and central levels. ${ }^{26}$ Mindful that it is not easy to develop a secret service and that its officers must be 'carefully chosen', he clarified: 'our old intelligence system has more or less broken down as it was bound to, because it was meant for different purposes, chiefly for tracking Congressmen and the like. The new intelligence service will have to be built differently'. ${ }^{27}$ As intelligence historian Paul McGarr notes, the 'handover of intelligence and security responsibilities was precipitate and problematic'. ${ }^{28}$ Neither did India receive access to existing intelligence dossiers, nor was it prised with knowledge of how such intelligence was gathered. Sardar Patel, India's first home minister noted that the British 'did not let us see or know anything' ${ }^{29}$ Even Guy Liddell, deputy chief of MI5, conceded that the IB 'was a mere shadow of its former self'. ${ }^{30}$ To fill the gap, instead of recreating the wheel, India appointed T G Sanjeevi Pillai as DIB in April 1947. Without any discussion on accountability, Sanjeevi was bestowed the responsibility to revamp India's domestic and external intelligence.

A police officer by training, Sanjeevi relied on his existing skills and contacts to fill the gap. ${ }^{31}$ Most IB officers in the post-independence era were 'hardboiled policemen' for whom the transfer of power simply meant a change in loyalty towards the Congress party. ${ }^{32}$ With active assistance from Mullik, Sanjeevi became preoccupied with conflicts in Kashmir and Hyderabad, in addition to targeting communist sympathisers within and outside the government for most part of 19489. ${ }^{33}$ But increasing intelligence demands by the political leadership required more resources, training, and effective intelligence management across state, central, foreign and defence sectors. Of the many ideas entertained on how to improve the organisation, one was to request external experts to visit India, and the other was to send an Indian officer abroad. Impressed by the Swiss intelligence, the Indian consul in Berne recommended seeking Swiss support on the former idea. But Sanjeevi was inclined to be sent abroad, and soon received an invitation from British security chief Percy Sillitoe to that effect. ${ }^{34}$ Despite finding such direct invitation to the DIB inappropriate and likely for Sillitoe's 'own purposes and to get his [Sanjeevi's] help in gaining information from India', Nehru authorised the tour. ${ }^{35}$ Meant only 'to study methods adopted there [Britain] to deal with intelligence' and not for Sanjeevi to 'tie himself with him [Sillitoe]', ${ }^{36}$ Nehru ensured that the DIB covered more countries, and included US, Switzerland, Canada, and Egypt on the itinerary. $^{37}$

India's intelligence organisation reflected its federal nature wherein central and state intelligence operated independent of each other, and the health of relations between the two depended on relations between their governments. ${ }^{38}$ External intelligence remained under the purview of the IB, but the armed forces retained independent intelligence arms and refused Sanjeevi's oversight. ${ }^{39}$ Many of the temporary subsidiary intelligence bureaus (SIB) were allowed to operate, especially in the border areas. ${ }^{40}$ Despite such decentralisation, Liddell noted, Sanjeevi sought 'almost dictatorial powers ${ }^{\prime 41}$ and was reported to run agents directly in provinces without the knowledge of his local officer. ${ }^{42}$ In London's estimation, if Sanjeevi was to do all that Delhi asked him, 'he will have to have an enormous Gestapo, which will cost the country a great deal of money and may well be corrupt and inefficient'. ${ }^{43}$ Eventually, Sanjeevi's standoff with senior Congressman Krishna Menon exhausted his goodwill with Nehru and Patel, who appointed Mullik as DIB in July $1950 .{ }^{44}$ Under Sanjeevi's leadership the IB became more reliant on Britain, even though London shared 'doctored intelligence' with India. ${ }^{45}$ As MI5 officers triumphantly noted: India 'could not do without our S.L.O. there at all. This is satisfactory'. ${ }^{46}$

With the death of Patel in December 1950, the IB's fortunes, and those of Mullik, depended on relations with Nehru. In theory, he was required to report external intelligence directly to Nehru who held the foreign portfolio. But given Nehru's political weight, Mullik used his channel to brief the premier on domestic security directly, instead of going via the Home Minister. Unregulated by legislative oversight, Mullik enjoyed considerable operational latitude, while simultaneously becoming tied to Nehru. ${ }^{47}$ In the domestic sphere, Mullik had support from a deputy and a few assistant directors and was in charge of all SIBs that worked with local police. In the 
foreign domain, the IB attached officers in Indian high commissions, embassies, and consulates in select countries. In 1952, for instance, Nehru acquiesced to the home ministry's request of establishing a reciprocal Security Liaison Unit (SLU) in London. In a letter to the high commissioner he articulated the parameters: (a) the SLU will have nothing to do with the Mission, (b) it will be 'completely under the Head of the Mission', and (c) it is not 'meant to keep watch in any way over our Indian student population as a whole or the Indian community in the UK' ${ }^{48}$ Nehru conceded that India's external intelligence capabilities required development, but the SLU was to 'know what Pakistan is doing ... as much of its activity is in London', and eventually extend its scope to the whole of Western Europe. ${ }^{49}$ By 1957, India's intelligence relationship with the UK deepened, even if the idea sat uncomfortably with India's desire to reduce reliance on the erstwhile colonial power. ${ }^{50}$

Such combination of limited external intelligence capability, adoption on policing methods and personnel for intelligence purposes, and the IB's dependence on the prime minister with no legislative oversight, generated peculiar structural contradictions. Whereas the IB could operate freely (and may even be abused if the political leadership so wanted), its scope and resources could just as easily be curtailed, making it vulnerable to an individual leader's views on the subject. $^{51}$ To this effect, Nehru's relationship with the IB was complex. Unlike Patel, who viewed intelligence as a critical arm of statecraft (coupled with anti-communist ideological impulses) and sought to strengthen it commensurately, Nehru remained ambivalent. To be sure, he appreciated the need for effective intelligence. This is visible in his repeated assertions to chief ministers and cabinet colleagues that: 'today [February 1948] more than ever we have to rely on proper intelligence. We are dealing with secret and underground people who have no scruples. I trust, therefore, that you will pay special attention to the development of an intelligence organisation'. ${ }^{52}$ But such institutions, whether at the central or the state level, required rebuilding in a way that suited postcolonial India's realities. Two parameters were critical: one, IB officers were to be objective and not view their work from political and ideological lenses; ${ }^{53}$ and two, they must not abuse power and track people indiscriminately.

Scarred from the experience of intrusive surveillance during the colonial period and his student days in England, Nehru became a critical consumer of intelligence. ${ }^{54}$ When outlining the parameters of the IB's SLU in London he categorically informed the Home Minister K N Katju in July 1952: 'During the British period, such shadowing took place on students, especially in foreign countries. I remember very well how angry I used to get at this type of shadowing on Indian students when I was myself a student in England. It was because of this that I took strong exception to any shadowing or watching of Indian students abroad. The only exception should be when there is some positive information about a particular individual'. ${ }^{55}$ Though sceptical of the 'police mentality' that might view complex issues in binaries, Nehru had little choice but to let IB recruit from the police. ${ }^{56}$ But he asserted that 'the wrong kind of person' who is 'not wholly reliable' must not be recruited. ${ }^{57}$ On various occasions he dismissed intelligence reports over his own assessment of situations, individuals, and groups under scrutiny. In a well-known 1954 letter to Mountbatten, he confessed: 'I always read our intelligence reports very critically and I am not prepared to accept them as they are. I have had a good deal of experience of the police and of intelligence from the other side to be taken in by the reports we get ${ }^{\prime 58}$ Be it about the political situation in the states, ${ }^{59}$ brewing communal and communist violence across the country, situation at the China border, ${ }^{60}$ developments in Kashmir and with Pakistan, ${ }^{61}$ or about select foreign nationals in India ${ }^{62}$, Nehru, convinced of his intellectual superiority, viewed intelligence reports as exaggerated.

The harshest criticism, however, was reserved for measures that Nehru saw as being unfairly invasive. Whether it was about the alleged harassment of Nepalese Congress leaders in India, ${ }^{63}$ or the IB's desire to track members of the Socialist Party, Nehru rejected the IB's requests (even if spying on the communists was considered fair-game, and political espionage against Congress' opponents was not discouraged). ${ }^{64}$ He once confessed to a 'feeling of shock' to C 
Rajagopalachari, Patel's successor as home minister, at the 'complete lack of intelligence' on the IB's part in issuing a secret circular that sought parents to give undertakings that their wards would not participate in political activities at schools and universities, and to offer 'lectures' to students advising them to 'keep away from Communism'. ${ }^{65}$ Such authoritarian tendencies, Nehru argued, were not suitable for democracies and visible in countries within the communist fold and, perhaps, in Franco's Spain. In a disagreement with Patel in December 1950 over the 'wrong[ful]' deportation of a Chinese schoolmaster and another Soviet national, Nehru stated that in police and intelligence reports he frequently comes across: 'accounts of people I know very intimately ... these comments are often quite wide of the mark, as I know from my personal knowledge. Hence one has to be a little careful about these judgments'. ${ }^{66}$ Not just intelligence assessments and methods, Nehru was critical even of the institution's judgment to allocate secret funds. ${ }^{67}$ Such criticism for intelligence did not emerge solely from Nehru's vision of how India must strike a balance between liberty and security, and harassment by imperial surveillance during the colonial period. British and American intelligence interventions during the Cold War in countries such as Iran, Guatemala, British Guiana, the Congo, Burma, and Chile further nurtured Nehru's distaste for intelligence. ${ }^{68}$

Despite being critical of the IB, and aware of Mullik's relatively 'right'-wing political persuasion, ${ }^{69}$ Nehru relied on the DIB and, even during the peak of the 1962 Sino-Indian border war, ${ }^{70}$ viewed him as: 'able, conscientious, and thoroughly straightforward'. ${ }^{71}$ There were instances when he accepted intelligence reports, and took relevant officials to task for either not responding in time to intelligence warnings, or for not taking care to keep the IB's activities secret. ${ }^{72}$ In May 1956, for instance, he complained to his private secretary about the ridiculousness of the situation wherein an office-bearer of the Hindu Mahasabha was a publicly known 'source' of central intelligence. ${ }^{73}$ Nonetheless, given India's comprehensive defeat in 1962, questions remain whether Nehru took adequate measures to strengthen intelligence institutions given his awareness of their value for decision-making. ${ }^{74}$ Being a cautious champion of intelligence was one thing but developing these institutions in earnest as per the standards that he sought of them was another. Moreover, in regions such as the Naga districts of Assam, parts of Kashmir, Punjab, and Bengal, as well as south India where Tamil agitation against Hindi domination was gaining momentum, the police and intelligence services routinely used coercive measures, making Nehru's concerns about the democratic rights of postcolonial citizens ring hollow. ${ }^{75}$

In March 1956, during an annual lecture on 'World Scenario and National Security' in Delhi to the Deputy Inspector-Generals (DIG) of Police, Nehru underlined the importance of intelligence, without which the decisions taken could be 'faulty'. ${ }^{76}$ On the issue of foreign intelligence, he asserted that India is 'more interested in our border countries'. Though he betrayed lack of knowledge about India's secret intelligence setup in London, the SLU was focused on Pakistan itself. $^{77}$ Based on an example of Britain's superior intelligence capacities against the Marathas who were militarily dominant in pre-colonial India, he ended his lecture on saying: 'real intelligence is most important both from our own as well as chiefly from the border countries'. ${ }^{78} \mathrm{His}$ emphasis on intelligence should have helped develop an effective service. But as events in 1962 demonstrated, the stress of war exacerbated existing strains in Indian intelligence. Delhi's decision-making systems collapsed due to skewed civil-military relations, politicisation of security institutions, and the IB's fatal assessment of Chinese intent of not escalating tensions despite military warnings to the contrary. ${ }^{79}$

The contradiction lay in Nehru's decision to continue with IB's pre-colonial organisational structure, bestow it with both domestic and foreign intelligence responsibilities, allow its officers to get trained in and develop liaison with the UK, but expect a different intelligence product. Even though he criticised IB for not being cosmopolitan in its quest for international support -as witnessed in his decision to expand Sanjeevi's travel itinerary beyond the UK in 1948- such efforts did not effectively dilute the New Delhi's reliance on London. The IB's institutional contacts with London after 1947, and a shared concern about the rise of communism ensured 
continuity of bias in favour of counterintelligence and domestic political intelligence. Unlike London's collaboration on SIGINT via GCHQ and counterintelligence via MI5 with wealthy white dominions of the Commonwealth, it focussed on countersubversion with its coloured excolonies. The Commonwealth Security Conference ensured that not just the IB, but also Pakistan's intelligence agencies, continued to select their targets in ways similar to their colonial predecessors. Even in the UK, the uncovering of the Cambridge-5 ensured the rise of 'red scare' within the government. ${ }^{80}$ This contradiction underlines the gap between Nehru and the IB's worldviews. It demonstrates the value Nehru put on the IB within security decision-making structures, and sought mitigating risks associated with the IB's colonial pedigree by being a critical consumer instead of recreating the wheel.

As following sections demonstrate, India's creation of Ghana's external intelligence services meant that the latter inherited the contradictions marking Indian. In 1966, four-years after India's defeat from China, Nkrumah faced a watershed moment. Instead of an overt push by an external power, his military officers ousted him in a military coup with support from a powerful intelligence apparatus. ${ }^{81}$ Regardless of the pressures that IB faced domestically, the global perception of India's successful struggle towards decolonising institutions created opportunities. Within a few months after Nehru's speech to the DIGs, he received Nkrumah's request to develop Ghana's intelligence service. Keen to strengthen India's position within the Non-Aligned Movement, to utilise India's experience of changing its intelligence after independence, and to reduce the country's foreign exchange crisis (Ghana offered India a loan of $£ 10$ million to be paid back over five years), Nehru accepted the offer after consultation with London. ${ }^{82}$ For Mullik, however, the Ghana assignment was less about strengthening India's image. It was an opportunity to sharpen the IB's foreign intelligence outreach and develop a multi-layered liaison network with other agencies operating in Africa.

\section{Made in India: 'a security service for Ghana'}

Nehru and Nkrumah's shared cosmopolitanism but different political circumstances explain why India accepted to create an external intelligence agency for Ghana, without having one for itself. Nehru sought to develop India's image as a peacemaker who rejected the dominant Cold War binaries. $^{83}$ In his worldview, an intelligence service was an important -but not paramount- tool for diplomacy and statecraft. It was needed for taking effective policy measures, but also needed to be limited in its ability to rampantly interfere in people's lives. The timing of India's independence in 1947 brought its own security problems, but it occurred before the intensification of the Cold War. Moreover, the Congress' pan-India outreach and representation, which developed during the nationalist movement, ensured Nehru's legitimacy. Despite his fears of a military coup, there was little opposition against Nehru. Nkrumah was a socialist grounded in Marxist-Leninist traditions focused on decolonisation of Africa, and a staunch advocate of pan-Africanism. There was commonality between the two leader's commitment to decolonisation, but stark differences appeared in their methods to realise such visions. ${ }^{84}$ In the face of violent opposition and increasing pressure from the two power blocs, Nkrumah had limited time to translate his ideological moorings into practice. He focussed more on political firefighting and managing acute shortages. Nehru's acceptance to support Ghana, thus, was grounded in postcolonial solidarity.

Mullik became the silent mastermind of Ghana's post-independence security setup. On 05 July 1957, before Nkrumah's formally sought India's support, Mullik authored a secret note for Nehru titled 'A Security Service for Ghana'. ${ }^{85}$ A comprehensive document that outlines his thinking on, and practical guidelines for, Ghana's security infrastructure, this hitherto unexamined document sheds light on Mullik's operational mind, and on Ghana's inheritance of the contradictions inhibiting Indian intelligence. There were five recommendations that Mullik made. One, Ghana's domestic intelligence should remain part of the police; two, the defence services should 
have independent intelligence arms focussed on military issues; three, the foreign ministry should have an intelligence arm operating through Ghana's missions abroad for collecting secret intelligence; four, though respectively under the control of the ministers of interior, defence, and foreign affairs, Nkrumah may see the chiefs of these intelligence arms 'regularly' to get reports from them and 'give them necessary instructions'; and five, a joint intelligence committee must be setup under the Secretary to the Cabinet of which the members will be the above-mentioned chiefs of intelligence. This committee will prepare regular reviews for Nkrumah and the Cabinet 'and also set the necessary targets'. ${ }^{86}$ In November 1957, after considering the matter and after consulting with London, Nehru shared the note with Nkrumah. ${ }^{87}$

Intelligence \& Policing: An illumination on the DIB's thinking and Ghana's management of the existing 6,000-strong police force, this note underlines certain paradoxes that led to Nkrumah's ouster in $1966 .^{88}$ To begin with, Mullik warned against creating a separate intelligence organisation under Nkrumah that is independent of the police, as 'this would arouse serious suspicion'. ${ }^{89}$ But, at the same time, his note paved the way for undermining the chain of command by asserting that chiefs of domestic, external, and defence intelligence could directly report to Nkrumah and seek instructions. In fact, he urged Nkrumah to take on the home minister's portfolio if he wanted security intelligence to reach him 'without his having to get it through his Home Minister'. ${ }^{90}$ If this was not feasible, then he recommended that the premier could order that all intelligence passed on by the Assistant Commissioner of Police-Special Branch (ACP-SB) must be sent in two copies, one to Nkrumah and the other to the home minister. To make his point unambiguous, he stated that there is nothing to prevent Nkrumah from giving orders directly to the Assistant Commissioner or the Commissioner 'and it is inconceivable that there will be any conflict about this between him and the Home Minister'. ${ }^{91}$ Given the history of differences between Nehru and Patel over political and intelligence issues, Mullik's assumption about ideational and political unity between the prime and home ministers is curious.

There could be different reasons for such an assumption. From Mullik's perspective, the primary intended audience of this note was Nehru, not Nkrumah. After stabilising the IB in the early years of the organisation, and developing Nehru's confidence despite stiff competition, Mullik is likely to have viewed this note as a testament of India's successful intelligence model. Herein, the DIB's access to Nehru was not just desirable, but necessary, even though his immediate boss was the home minister. To suggest otherwise could undermine the efficacy of this carefully curated intelligence-customer relationship. Moreover, the note demonstrates that despite voicing concern about a separate intelligence agency operating under Nkrumah, Mullik actually favoured such an organisation in practice. In fact, his suggestion was quite literal i.e. a 'separate' or new intelligence agency that is created by and operates under Nkrumah will inevitably attract suspicion. Instead, the Ghanaian leader must exert control over existing internal intelligence structures within the police force. He underlined this point by offering analysis on the Ceylonese (later Sri Lanka) situation. In 1953-4, John Kotelawala, Ceylon's third prime minister, created an intelligence branch under his control separate from the police. The move created such apprehension that when S W R D Bandranaike came to power in April 1956, the first thing he did was to scrap the organisation. As a result, Mullik laments, 'the Ceylon, at present, has practically no intelligence organisation worth the name and has to start from the beginning again'. ${ }^{92}$

Ironically, the FSRB, created for foreign intelligence purposes, ended up becoming exactly the kind of organisation Mullik warned against. In combination with Nkrumah's control over the special branch, the FSRB attracted suspicion from both domestic constituents and neighbouring states wary of Nkrumah's pan-Africanism. ${ }^{93}$ The only difference between what Mullik recommended for Ghana and the setup in India was the creation of an external intelligence arm that operated under the foreign ministry. As noted previously, in India foreign intelligence was within the purview of the IB, its scope was limited to India's neighbourhood, and wherever intelligence officers operated from missions abroad, they had to respect the mission-chief's authority. In Ghana's case, the FSRB was created by a prime ministerial directive, staffed based on loyalty to 
Nkrumah, and had direct access to the leader. Mullik was aware that the FSRB would 'become quite important' overtime, and 'will be an indispensable part of the foreign office'. ${ }^{94}$ But his ambiguity on this issue -he did not explicitly argue that a separate foreign intelligence organisation must not be created; his point on separation of domestic intelligence from police work was meant for internal security- created a conceptual loophole that undermined the essence of his note. His recommendation that the three intelligence chiefs could reach out directly to the prime minister and seek instructions endowed upon Nkrumah unchecked power. It paved the way for a breakdown of the chain of command and undermined the authority of Nkrumah's political allies within and outside the CPP. It likely oxygenated his ideas of becoming Ghana's presidentfor-life.

Colonial Continuities: The other paradox of Mullik's note lay in its spectacular, if expected admission of continuity in both India and Ghana's reliance on police structures created by the colonial administration. ${ }^{95}$ His idea to strengthen the marriage of Ghana's national police and intelligence, though practical, single-handedly undermined Nkrumah's desire for decolonisation. In many ways, it was a repeat of what occurred in India i.e. the transfer of loyalty of police officers from the colonial administration to the new political dispensation. Mullik's point was simple: 'in any internal security organisation the police have a very important part to play. Where there is a nationalised police force as in India or Ghana ... it would be unwise to separate intelligence functions from the police'. ${ }^{96}$ This was because the police already collected intelligence for law and order purposes, and a separate organisation, divorced from the police, would 'involve a considerable wastage of money and manpower', fuel jealousies, and work at cross-purposes. ${ }^{97}$ But such continuity also meant that police officers trained by the colonial administration, just like in India, would utilise colonial techniques and routinely resort to violence.

Police Organisation: Organisationally, Ghana's Commissioner of Police was equivalent to an Inspector-General in Indian states. Each province then had its own Assistant Commissioner of Police (equivalent to DIGs in India), just like the two posted in the headquarters in Accra: one responsible for criminal investigation and the other in-charge of the SB. ${ }^{98}$ The SB was critical for intelligence purposes during the colonial administration, and Mullik recommended continuing it. $^{99}$ Overseeing a parallel setup right to the local police station level, the ACP-SB had his own provincial superintendent doing intelligence work in addition to other superintendents who reported to provincial ACPs. Plus, in every police station, the ACP-SB had an inspector doing intelligence work, in addition to the inspector who ran the station. Intelligence reports were sent from inspectors to district superintendents. They would collate all intelligence generated from the police stations, add what they gathered through their own sources, and send the report to the provincial SB officer. This officer updated the report based on his own inputs and forwarded it to the ACP-SB -giving this individual tremendous power. As Mullik noted, this 'system works exactly the same way as in an Indian state and this is to be expected as there is lot of similarity of British administration in the colonies and in India'. ${ }^{100}$ The key difference between Ghana and India, however, was that the latter was a large federal democracy where policing was a state issue. Unlike India's federal devolution that offered structural checks against abuse of power, such was not the case for Ghana that was a one-party state for all practical purposes. ${ }^{101}$ Mullik's faith in combining policing and intelligence was such that he even criticised the UK's security organisation. Bereft of national police, he argued, London 'had no centralised organisation to collect and collate political intelligence'. It was for this reason London needed a separate Security Service (MI5), which suffered from various 'handicaps' that are not visible in the case of India's IB.

In effect, Mullik's note, though logical, blunted Nkrumah's desire for decolonisation of Ghana's security services by emphasising the importance of colonial policing and intelligence. This approach ended up guaranteeing politicisation of Ghanaian intelligence. Mullik also paved the way for policing methods to influence intelligence work, an aspect that Nehru was ambivalent about, even if he did little to change it. The most glaring continuity from the colonial to the 
postcolonial intelligence for Ghana, however, was the lack of legislative oversight. Mullik did not mention these aspects even once in the note. The special branch soon developed a reputation of being ruthless for detaining Nkrumah's opponents, and sliding the country into authoritarianism. According to historian Calder Walton, MI5's failure to train local Ghanaian SB officers as non-political intelligence professionals during the colonial period, empowered Nkrumah's authoritarian rule after $1957 . .^{102}$ To be sure, communication in 1953 between the British SLO based in Accra and MI5's London HQ, reflect that London was aware of Nkrumah's personal ambitions and its associated risks. ${ }^{103}$ Though biased, the SLO, whose job was to keep close tabs on Nkrumah, viewed the Ghanaian leader's 'innate weakness of character' as the cause for mishandling party-political issues and growing communist influence. ${ }^{104}$ To comment on, or offer institutional guidance based on colonial reading of Nkrumah's personality were beyond Mullik's remit -if at all known to him. To that extent, the impact of his note on Ghanaian intelligence and their relationship with Nkrumah was unwitting. Moreover, Nkrumah did continue to recruit British support directly in addition to seeking Indian help. In May 1958, he appointed a committee to deal with national security comprising of British, Canadian, and Pakistani officers. This was a quandary for Delhi, which did not want to be in the same capacity-building tent as Pakistan but did little about it. As Kao puts it: 'though I spent over a year in Ghana, I never got to know what precisely this committee did'. ${ }^{105}$ The impact of this committee remains unclear, but it doesn't seem to figure big in Accra's decision-making -underlining the importance of the relationship between Ghana's intelligence chiefs and Nkrumah. Just like in India, Ghana's intelligence services were deeply tied to the prime minister.

The political and security circumstances of these leaders -or how they viewed their circumstances- had a decisive impact on the role and efficacy of their intelligence services. Unlike India, which became independent before the Cold War intensified, Ghana didn't have such luxury. The Congress' institutional strength, Nehru's public appeal coupled with paramount policy influence and a democratic polity enabled him to remain critical of IB while also relying on Mullik. For Nkrumah, who faced multiple assassination attempts and intelligence-led intrigue by the Western and the socialist blocs, there was limited space for political experimentation. Despite his democratic, cosmopolitan, and internationalist worldviews, the ground realities militated against easy development of institutions despite a large reserve of foreign exchange that Accra used for developing these institutions. Dominated by policing culture, and manipulated by London, Paris, Washington D.C., Moscow, and Beijing's 'Cold Warriors' in 1966, the very institutions that Nkrumah developed to advance his ideology and for Ghana's security, especially SB and the defence forces-turned against him. ${ }^{106}$

\section{The foreign service research bureau: an 'experiment' ${ }^{107}$}

Mullik proposed a three-staged plan to create the FSRB. In the first stage, the DIB was to visit Ghana for two-three weeks. There he intended to discuss the problems with the government, ascertain their 'targets', and make an estimate of available human resources both in the services and outside. Based on this information a detailed plan for setting up of the service was to be developed for Nkrumah's approval. ${ }^{108}$ In the meantime, simultaneous preparations were made in New Delhi to receive two-three Ghanaian officers for training. They could not be trained in Ghana itself because a team of at least six Indian officers was required; and some of the equipment may not be available in Accra. The second stage entailed the training of Ghanaian officers for 'four to six months depending on the targets which are fixed for the Ghana External Intelligence Service'. ${ }^{109}$ In the third stage, an Indian officer was to be stationed in Accra for about a year, and, with the help of the Ghanaian officers trained in India, 'he will gradually set up the service, select the staff, and arrange for local training', but only in a supervisory capacity. ${ }^{110}$ On this point Nehru was clear that 'the officer-in-charge ... should not take over as the 
head of the new service even temporarily', even if Nkrumah preferred that. ${ }^{111}$ Nehru recommended that till the time a Ghanaian officer is selected to lead the service, the Cabinet Secretary or an equivalent officer could control the organisation.

For unknown reasons, Mullik never visited Ghana. But he ensured that the British-SLO in New Delhi was kept informed about these developments. As one of the Indian officers who went to Ghana put it, 'even if in their heart of hearts they were perhaps unhappy that Ghana should go to India for an expert instead of asking UK for one, they pretended to like this arrangement and tried very suddenly to guide the working of this scheme if only through personal hints and the lightest of suggestions'. ${ }^{112}$ The Indian officers selected for the assignment were Rameshwar Nath 'Ramji' Kao (1958-60) and K Sankaran Nair (1959-61). ${ }^{113}$ They became the architects of FSRB and its unofficial but effective chiefs during 1958-61. Why these two officers were chosen in particular remains unclear, but neither had prior experience in setting up an intelligence institution. Expectedly, questions about the quality of their training support remain. Interestingly, during this period, Pakistan was competing with Indian presence in Africa, and raised questions about quality of India's service delivery. In a candid admission to the British High Commissioner in Karachi, senior Pakistani diplomats conceded that India 'had been stealing a march over Pakistan, particularly in Ghana'. ${ }^{114}$ However, they were alleged that the Ghanaians were 'very dissatisfied with the quality of the Indian service instructors ... and also with the quality of some training aircraft that the Indians had dumped on the Ghanaians'. ${ }^{115}$ Given the vast scope of India's training support to Ghana, it is unclear whether Pakistan meant Kao and Nair in particular. It is equally possible that they exaggerated Indian training deficiencies to boost their own presence in Ghana. The Ghanaian officers who visited India for training were Supt. Paul Yankee and Dy. Supt. Benjamin 'Ben' Forjoe (April-July 1958). ${ }^{116}$ The sources of information about how Kao and Nair went about their work in Ghana emerges from the former's unpublished private papers and the latter's memoirs. ${ }^{17}$ For scholars working on Indian intelligence, these are known accounts, and Kao's experience has been narrated verbatim in existing journalistic works. ${ }^{118}$ Instead of repeating these accounts, this section unpacks aspects from these accounts about how India trained Ghanaian officers, what the assignment meant for Indian officers, and where it fit in Nehru's vision about India's role as a global peacemaker. ${ }^{119}$

Toxic Loyalties: One of the most pronounced themes emerging from Kao and Nair's accounts is the centrality of partisan loyalties towards Nkrumah for any Ghanaian national who wanted to be part of the FSRB. Forjoe and Yankee were from the same Nzema tribe that Nkrumah belonged to and were 'intensely loyal' to the leader. ${ }^{120}$ According to Nair, Nkrumah trusted Yankee 'like his right hand' and marked him out as the future chief-FSRB. ${ }^{121}$ Forjoe too won Nkrumah's confidence by his 'loyalty and uprightness'. ${ }^{122}$ Discreet and conscious of the fact that they had been selected to break fresh ground in the field of foreign intelligence, both Forjoe and Yankee worked hard during their time in India. On reaching Accra, Kao realised that Nkrumah had handpicked twenty-one persons, aged between 21 and 49, who were to be taken into the secret service. This was an interesting development because Kao was supposed to recruit personnel after coming to Accra. Nkrumah's pre-selection of officers without consultation with Kao underlines the importance he attached to filling the FSRB with loyalists over professionals. This stood out in light of the fact that neither Forjoe nor Yankee had done anything since their return from India (they didn't even inform their government about their training) and waited for Kao to arrive to begin from scratch. ${ }^{123}$ Not one of Nkrumah's recruits was a graduate, and all were previously employed in different sectors. Such pre-selection ensured that most FSRB officers were indebted to Nkrumah personally. A sign that Nkrumah used the organisation to develop patronage, one of the men opted for the organisation was working in Ghana's trade union congress and another one was an employee of the CPP. ${ }^{124}$ There is no evidence that Kao challenged Nkrumah's recruitment decisions, thereby permitting the politicization of the organisation from the outset. 
Further confirming this theme of loyalty towards a single leader was the kind of access Kao and Nair enjoyed with Nkrumah. Politically non-threatening, Indian officers fulfilled the dual role of developing a new intelligence service staffed with loyalists and kept up the veneer of distancing from the British. This was visible in Nkrumah's decision to expand the scope of Kao's work to both counterintelligence and 'positive' intelligence. He asked him to oversee not just the FSRB but also the SB, which was still being led by a British official Jim McKay. Though 'overwhelmed' by the magnitude of his responsibility, Kao admits that he never faced any opposition in doing his job. Throughout his stay in Ghana, Kao writes, he never felt 'even the slightest suspicion of dubiousness or duplicity in Dr. Nkrumah's behaviour towards me ... he was frank and free and friendly'. ${ }^{125}$ The fact that Kao and Nair didn't have local political ambitions enabled unfettered access to Nkrumah. So much so that Nkrumah directed the Ghanaian foreign office to extend Kao all the privileges that the Indian High Commission in Accra denied him. ${ }^{126}$ To be sure, many people correctly considered Kao and Nair as 'outsiders' and 'resented the total trust' that Nkrumah had placed in them for this reason. But the 'wrinkles' created by these people were 'unobtrusively removed' by Nkrumah's secretary. ${ }^{127}$ As a sign of appreciation -and political requirement- Nkrumah asked both Kao and Nair to extend their stays in Ghana, only to be politely refused.

An intelligence institution that relies on one individual for its existence and nourishment, and creates unquestioning bonds of loyalty with this individual, can become dangerous. To a much lesser extent than the IB in India, the FSRB and SB became tools for Nkrumah to attempt and become president-for-life and a pan-African leader competing with Egypt's Gamal Abdel Nasser. Such unity of command and control, however, ensured that Ghanaian intelligence was susceptible to institutional decay. Another example of how Nkrumah developed toxic dependencies in the FSRB is visible in the transition moment when Nair had to leave for India and handover the reign of the organisation to a Ghanaian officer. Yankee, who had been Nkrumah's favourite for the role, had died in a mysterious 'car crash' in late-1960. ${ }^{128}$ The next day, after condoling Yankee's loss, Nair recommended Forjoe's name as chief-FSRB. Instead of accepting the proposition, Nkrumah deferred the decision. Few months later, when it was time for Nair to leave for India, he recommended Forjoe's name again. Once more, instead of accepting the suggestion, Nkrumah asked Nair to continue in the position for another year. In the face of opposition to such an extension (Nair didn't want to make Ghanaian officers angry by blocking their promotions), Nkrumah accepted Forjoe's promotion with the caveat that Nair would continue for another six-months. ${ }^{129}$ Clearly, Forjoe did not enjoy the same level of trust and confidence with Nkrumah as Yankee did -but ended up becoming one of the most powerful intelligence chiefs in the history of independent Ghana. ${ }^{130}$

Intelligence and Political Opportunities: The Ghana assignment held different professional and geopolitical value for India's intelligence and political leadership. For IB officers the opportunity offered by the 'delicate' Ghana assignment lay not in its impact on India's global image as a peacemaker, but in what it brought to the table for the IB itself. Not experienced in creating or operating an external intelligence organisation of its own, the Ghana assignment offered institution-building experience as well as expanding and strengthening IB's international partnerships. Quickly ironing out bureaucratic hindrances to Kao's deputation, Mullik kept in touch with MI5 about the role IB was asked to play in Ghana. ${ }^{131}$ When in Accra, Kao welcomed when British officers McKay and MI5's SLO John Thompson made 'special efforts to be friendly' with him. ${ }^{132}$ Similar to the experience he had when visiting Hong Kong to investigate the 'Kashmir Princess' case, Kao felt 'reassured' by the attention he received from the British. ${ }^{133}$ His posting in Ghana allowed him to deepen IB's links with MI5 outside Nehru's gaze and that of his own colleagues. Such a partnership with the MI5, Kao writes, was 'substantially useful' not just in Ghana but also afterwards. $^{134}$

Kao ensured that Nair did not miss the opportunity when the latter sought his views prior to accepting the posting in 1959. 'In later years, I realized that his advice was one of the best that I 
had ever received', states Nair, who didn't just develop IB's contacts with the British, but also with the CIA's Accra Station Chief, and that of Israel's Mossad. ${ }^{135}$ Israel enjoyed positive public perception in Ghana, and made considerable inroads into the country by offering Nkrumah fighter jets for the Ghanaian Air Force (years later, after Nkrumah's ouster, Mossad also trained Forjoe in counter-intelligence). ${ }^{136}$ The Mossad representative reached out to Nair more than once seeking help to convince New Delhi to recognise Israel. Though Nair's stoic silence on this count ensured that Mossad lost interest in him, the IB developed a covert relationship with Mossad during the 1960s, which gained momentum during Indira Gandhi and Golda Meir's leadership. ${ }^{137}$ To this effect, operating in Ghana allowed IB to expand its outreach within Africa, but also outside the continent. With the CIA, Nair learnt the lesson of intelligence leaks the hard way when his confidential briefing on the situation in Ghana to the CIA officer in Accra was reported almost 'verbatim' in the Time magazine's next edition. ${ }^{138}$ These experiences and networks helped IB improve its capabilities outside India.

For this reason, India's intelligence leaders viewed access to Ghana as being more important than ensuring Yankee and Forjoe's success as intelligence officers. As Kao admits, the IB had recognised from the beginning of the Ghanaians' arrival in New Delhi that it was more important 'for us to make a good impact' on these officers, and 'to make them feel that they were amongst friends'. ${ }^{139}$ The actual theoretical knowledge about foreign intelligence operations was 'regarded as a matter of secondary importance'. ${ }^{140}$ Apart from foreign travel, good salaries, and expanded intelligence networks, the Ghana assignment also exposed Kao and Nair to hostile environments (from a Ghanaian perspective) and to practice their tradecraft in European and African capitals. In 1961, for instance, Nair visited Paris with his Ghanaian colleagues. After finishing their meetings at the mission, they decided to relax at a café in Champs Elysee'. But on their way Nair noticed an entourage silently following them. Quickly guiding his team into a blind alley, Nair took a sharp turn out on the other side -only to find a different team following them there. To disconcert this surveillance group, he went up to one of the men and requested a cigarette light. In the process, his suspicions of multiple surveillance teams following them were confirmed. Later, he found out that these were French counter-intelligence officers interested in Nair and his men because the FSRB was sheltering 'agitators' from French Cameroon in its Parisian embassy. ${ }^{141}$

Unlike the intelligence leaders of India, Nehru viewed the Ghana assignment as an assertion of India's position as global peacemaker and leader of the Non-Aligned Movement. With memories of the 1956 Suez Crisis afresh, Nkrumah's request to Nehru for developing an external intelligence agency offered India a better grasp of the West African situation, and to balance between Ghana and the United Arab Republic (UAR; which was led by Egypt's Gamal Abdel Nasser). For instance, by early 1957 itself Nehru had agreed to represent Ghana's interests in Saudi Arabia, Egypt and Syria till the time Accra developed its own foreign affairs capabilities. ${ }^{142}$ Such positioning allowed Nehru to buttress India's credentials within the Afro-Asian solidarity network. Throughout this period, based on a huge reserve of foreign exchange from Ghana's cocoa exports, Nkrumah was actively encouraging freedom struggles in South Africa, Namibia, Swaziland, and other colonised African territories. ${ }^{143}$ He eventually instructed Kao that the FSRB must target the French occupied territories surrounding Ghana as a matter of priority. This should be followed by the UAR whose embassy was doing 'a lot of offensive intelligence work' in Ghana, and then to monitor British and American activities. ${ }^{144}$ Though less concerned about Soviet and Chinese communism, he wanted Kao to assess and review 'Russian design and international communist activities' in Ghana in that order of priority. ${ }^{145}$

Such intelligence work allowed India to make inroads into Ghana without jeopardising relations with London, and to develop valuable transferable skills and expertise. In 1960, soon after Nkrumah became president and before Nair left Accra, Ghana created the Bureau of National Security (BNS) that was meant to 'coordinate and direct more effectively the security and intelligence services of the country'. ${ }^{146}$ Conceptualised by Mullik as a joint intelligence committee, creation of the BNS under the Secretary of the Cabinet, was the final stage of India's support to 
Ghana in developing its security setup. An indication of the success of India's diplomatic moves vis-à-vis Ghana is visible in Nkrumah's 1958 India visit where he sought support for developing nearly all of Ghana's institutions and to increase bilateral trade. ${ }^{147}$ Just before he flew for Delhi, Ghana's Permanent Secretary, A. L. Adu, informed the Indian high commissioner that, from a political angle, he would like Nkrumah 'to sit at the feet of Mr. Nehru'. ${ }^{148}$ Nkrumah sought to 'learn' from the Indian leader in the early days of his premiership. In reality, he had begun to drift towards authoritarianism, and India unwittingly empowered this drift.

\section{Conclusion}

Soon after Nair's departure from Accra, Ghana witnessed a sharp uptick in Soviet and Chinese offensive espionage. Nkrumah survived five different assassination attempts, at least one of which was allegedly sponsored by the KGB. ${ }^{149}$ Failure of these assassination attempts led the KGB to begin a concerted disinformation campaign to deepen Nkrumah's suspicion of Western powers. ${ }^{150}$ Convinced of Nkrumah's impending shift into becoming a Soviet satellite, in 1966, the CIA and MI5/6 did eventually orchestrate a coup against him and made the new government evict nearly 1,000 Soviet advisors from Accra. ${ }^{151}$ Instead of acknowledging India's inability to create an institution that would withstand or temper Nkrumah's style of governance in a very turbulent context, Kao blamed the 'distorted influence' of the Soviet Union and China for changing Nkrumah's 'old style of working'. ${ }^{152}$ But the fact remained that while ensuring continuity between colonial and postcolonial policing structures, and also creating a new foreign intelligence organisation for Ghana, Mullik failed to mention the key pitfalls that might hinder Ghana's development as a democracy i.e. Nkrumah's use of intelligence as a political weapon. Total lack of accountability, the continuation of recruitment in the FSRB along partisan loyalist lines, and the SB's pervasive information networks coupled with Cold War intrigue enabled Nkrumah's authoritarian side after he become president in 1960.

The point that emerges from Mullik's secret note was that it didn't foresee how his policingheavy security structures might develop in Ghana's case. He did note that Ghana's situation cannot be compared with India but did not factor the risks that came along with an empowered intelligence service in a highly securitised context. Apart from being a parliamentary democracy, India inherited a cadre of highly trained bureaucrats and political heavyweights that worked as a check against Nehru's excesses (even if such checks were less successful with his daughter). Nkrumah's turn to paranoia and authoritarianism, as the MI5 had foreseen in 1955, was aided by a combination of weak institutions, political ambitions, and intense Cold War turbulence. ${ }^{153}$ Unlike India, where Nehru continued to resent the IB's policing methods and often rejected their intrusion into people's privacy (or resorting to heavy-handed tactics in order to counter real or imaginary threats from communism), Nkrumah had little choice but to embrace these institutions to meet his political aims. To that effect, Nkrumah's decolonisation project remained stunted for both external and internal reasons. Even though he succeeded in reducing overt British influence in Ghana, he received more or less exactly what Britain would have offered, but via India.

Indian intelligence institutions, for their part, came full circle in 1968. Indira Gandhi sought Kao's services to create India's first external intelligence service. At that point, during an official tour to London in November 1967, Kao received a call from the then cabinet secretary, who informed Kao about Gandhi's decision to bifurcate the IB and create a separate organisation for foreign intelligence. Joshi asked Kao to prepare a concept note based on his past 'experiment' in Ghana. ${ }^{154}$ Unlike Nehru, who allowed Mullik to operate the IB along policing lines while expecting a different product, Gandhi desired serious reforms. She instructed Kao neither to replicate IB functioning that was 'an old wine in new bottle', nor to 'create a police organisation', but to develop 'modern intelligence based on developments all over the world'. ${ }^{155}$ Kao went about studying intelligence structures and methods of countries as diverse as the US, UK, Soviet Union, 
Germany, Japan, France, and Israel, and came up with a flexible 'pilot scheme' to see how a similar institution might work best for India. The officer he sought to recruit as his deputy in this institution was Nair. ${ }^{156}$ Soon after, on September 21, 1968, India's external intelligence agency, the Research and Analysis Wing (R\&AW) was created with Kao as its chief (or Secretary-Research) and Nair as Additional Director-R\&AW. Ever since, both the IB and R\&AW have played a pivotal role in dealing with India's domestic and external security challenges. ${ }^{157}$

Given the paucity of archival material on both R\&AW and IB, a systematic analysis of India's intelligence remains onerous. But focus on its creation of the FSRB sheds light on Delhi's approach towards intelligence. True, it does not offer a complete picture of India's intelligence practices. But it enables to glean the essence of how India's political and intelligence leaders thought about these issues, especially because the Ghanaian exercise was so fundamental i.e. creating an entirely new intelligence service. Apart from the historical value of such an understudied case, India's intelligence collaboration with Ghana highlights change and continuity in security practices during the colonial and postcolonial period for two different countries and contexts. In the long term, despite inheriting similar security structures, India's political experience with democracy was more successful than Ghana's. But intense political turmoil and violence in the first four decades of independence meant that when Ghana did introduce democratic reforms in 1996, it ensured legislative accountability of its intelligence agencies. Since 1992, civilian control over intelligence agencies has become a fundamental constitutional principle in Ghana. ${ }^{158}$ Moreover, the Security and Intelligence Agencies Act of 1996 ensured more -if not complete- democratic control over Ghana's intelligence agencies. In that sense, Ghana decolonised its intelligence services in a truer sense relative to India, where there is still no accountability of intelligence agencies. In fact, the Intelligence Services (Powers \& Regulation) Bill, introduced in 2011 by then-in-power Congress parliamentarian has not passed as law till today. ${ }^{159}$

This study of India and Ghana's approach towards intelligence structures and practices underscores the limits of decolonisation in Asia and Africa in 1950s. Nationalist elites of these countries, continued to rely on ideas, networks, and institutions of governance that were closely knit with Britain's global colonial architecture in the form of the Commonwealth. Often a target of colonial intelligence apparatus, leaders of independent Ghana and India developed peculiar relationships with these institutions once in power. For Nehru, they were essential to statecraft and needed careful development to remain effective but not excessively intrusive. Even though he failed to reform Indian intelligence and lamented IB's reliance on policing methods and personnel, he tried reconciling the dilemma of India's secular democratic make with the demands of domestic intelligence, which sought to intrude upon the privacy of individuals and groups. In India, the cumulative failures to seriously reform external intelligence in the first decade of independence were reflected in the debilitating loss to China in 1962. Not only did its command-and-control fall apart in the light of an external military shock, contrasting intelligence assessments reaching Nehru about Chinese intent became increasingly complicated and contested. ${ }^{160}$ Ghana, however, went in a completely different direction as Nkrumah privileged loyalty over professional calibre and the country slid into authoritarianism. Soon to become a focal point of the Global Cold War, the lack of strong democratic institutions in Ghana ended up in Nkrumah's forced ouster in a West-led coup in 1966.

\section{Notes}

1. Melanie Torrent, 'A 'New' Commonwealth from Britain? Negotiating Ghana's Pan-African and Asian Connections at the End of Empire (1951-8)', The International History Review, 38(3), 2016, 573-613; Dennis L Cohen, 'The Convention People's Party of Ghana: Representational or Solidarity Party?', Canadian Journal of African Studies, 4(2), Spring 1970, 173-94; Frank Gerits, "When the Bull Elephants Fight': Kwame Nkrumah, Non-Alignment, and Pan-Africanism as an Interventionist Ideology in the Global Cold War (1957-66)', The International History Review, 37(5), (2015), 951-69.

2. Dennis Austin, 'Opposition in Ghana: 1947-67', Government and Opposition, 2(4), July-October 1967, 539-55. 
3. Nehru's The Discovery of India and Gandhi's works had an impact on Nkrumah. Calder Walton, Empire of Secrets: British Intelligence, the Cold War, and the Twilight of Empire (London: William Collins, 2013), 213.

4. Dipesh Chakrabarty, 'Legacies of Bandung: Decolonisation and the Politics of Culture', Economic and Political Weekly, 40(46), November 12-18 (2005), 4812-8; Neera Chandhoke, 'Jawaharlal Nehru's Radical Cosmopolitanism', Economic and Political Weekly, 49 (47) (22/11/2014), 37-40.

5. Nkrumah's letter to Nehru is not available, but Nehru's response to Nkrumah is. Government of India (Gol), Nehru to Nkrumah, 22/01/1957, Jawaharlal Nehru (JLN) Papers, SECRET AND PERSONAL, 99-PMH/57, NAI.

6. Ibid; In the meantime, the GCHQ from London was offering cypher and code technologies to Ghana in order to secure their communications. And in that way, duplicitously, spying on Nkrumah and his Cabinet. Walton, Empire of Secrets, 229-30.

7. 'Ghana Episode', File 03, RN Kao Papers, NMML, p. 2.

8. Gol, BK Kapur (Accra) to MJ Desai (Delhi), 22/12/1957, Ministry of External Affairs, SECRET, P.2(52)/57, NAI. Ghana sought to hire nearly 233 engineers, educationalists, doctors, railway experts, locomotive superintendents, agriculturalists, and radio engineers from India. Ghana offered attractive emoluments for these hires based on the funds that were freed due to the departure of 800 British experts. At the time of independence Ghana had a cadre of 4,000 public servants, of which it could, at maximum, fill only 45 per cent with African personnel due to limited capacities.

9. 'Ghana Episode', File No. 3, R N Kao Papers, Nehru Memorial Museum and Library (NMML), 2. Nkrumah also sought Indian support for the creation of the Ghanaian Air Force. Nehru to Nkrumah, 23/11/1958, Selected Works of Jawaharlal Nehru (SWJN), 2(45), Nov-Dec 1958, 743.

10. 'Ghana Episode', Kao Papers, 2-3.

11. Gol, Nehru to Nkrumah, 28/11/1957, JLN Papers, SECRET, 2391-PMH/57, NAI.

12. Emmanuel K. Aning, Emma Birikorang, Ernest A. Lartey, 'The Processes and Mechanisms of Developing a Democratic Intelligence Culture in Ghana', in Philip H J Davis and Kristian C Gustafson eds. Intelligence Elsewhere: Spies and Espionage Outside the Anglosphere (Washington DC: Georgetown University Press, 2013), 199-206.

13. Basil Davidson, Black Star: A View of the Life and Times of Kwame Nkrumah (Abingdon: Routledge, 1989).

14. D Apter, 'Nkrumah, charisma, and the coup', Daedalus, 97(3), Summer 1968, 757-92; Walton, Empire of Secrets, 231-2.

15. Saawani J Raje, 'Decision in Crises: A history of Civil-Military Relations in India, 1947-71', doctoral thesis, King's College London, 2020; Anit Mukherjee, The Absent Dialogue: Politicians, Bureaucrats, and the Military in India (Oxford: Oxford University Press, 2020)

16. Zorawar D Singh, Power and Diplomacy: India's Foreign Policies During the Cold War (New Delhi: Oxford University Press, 2019). For more on India in Africa after independence, see Emma Mawdsley \& Gerard McCann eds., India in Africa: Changing Geographies of Power (Cape Town: Pambazuka Press, 2011), 1-10.

17. Gol, 'Deputation of Mr. T C Sanjevi I. P. Director Intelligence Bureau', Ministry of Home Affairs, Police-II, SECRET, 1949, NAI 40/21/49; Paul McGarr, 'India's Cold War Spy Chiefs: Decolonizing Intelligence in South Asia', in Paul Maddrell et al. eds. Spy Chiefs: Intelligence Leaders in Europe, the Middle East, and Asia (Washington DC: Georgetown University Press, 2018), 183-2-4.

18. Walton, Empire of Secrets, 229.

19. Richard J. Popplewell, Intelligence and Imperial Defence: British Intelligence and the Defence of the Indian Empire, 1904-1924 (London: Routledge, 1995).

20. Srinath Raghavan, War and Peace in Modern India (London: Palgrave Macmillan, 2010) and Ramachandra Guha, India After Gandhi: The History of the World's Largest Democracy (London: HarperCollins, 2007)

21. The senior-most intelligence officers from the IB opted for Pakistan. Raghavan, War and Peace in Modern India, 24.

22. Guy Liddell Diaries, May 05, 1948, UK National Archives (UKNA), KV/4/470, 91.

23. Christopher Andrew, The Defence of the Realm: The Authorized History of MI5 (London: Penguin, 2010), 444-5; In addition to the SLO, the Indian Political Intelligence unit of the MI5 had ten officers. Liddell Diaries, 22/06/ 1949, UKNA, KV/4/471, 132-3.

24. Liddell Diaries, 05/05/1948, KV/4/470, 91.

25. These concerns, among other things, emanated from Nehru's anger over the IB's inability to foresee communal rioting in Delhi in 1947. Nehru to Patel, 06/10/1947, SWJN, 2(4), Aug-Dec 1947, 127.

26. Nehru to Premier of Provinces, 02/11/1947, SWJN, 2(4), Aug-Dec 1947, 447.

27. Ibid

28. McGarr, 'India's Cold War Spy Chiefs', p.183

29. Quoted in McGarr, 'India's Cold War Spy Chiefs', p.184

30. Liddell Diaries, 05/05/1948, KV/4/470, p.91

31. P C Dheeraj, 'Strategic Intelligence in India through the case studies of 1962, 1971, and 1999 wars', doctoral thesis, University of Leicester, 2020.

32. R K Yadav, Mission R\&AW (Delhi: Manas Publishers, 2014) p.24 
33. He allowed Elmhirst to oust nearly 600 officers from the Indian Air Force who were deemed Communist. Liddell Diaries, 05/05/1948, KV/4/470, 91-2.

34. Nehru to Krishna Menon, 26/01/1949, SWJN, 2(9), Dec 1948-Feb 1949, 391-3.

35. Nehru to Krishna Menon, 02/12/1948, SWJN, 2(8), 368-69.

36. Ibid

37. Gol, 'Deputation of Mr. T C Sanjevi I. P. Director Intelligence Bureau', MHA, Police-II, SECRET, 1949, NAI 40/21/ 49 Sanjeevi developed close relations with British and American intelligence, and was enamoured by the CIA more than the FBI, McGarr, 'India's Cold War Spy Chiefs', 189-91.

38. Sanjeevi confided in Sillitoe his worries about a potential situation where the central and state governments may be formed by different political parties, making the IB's role difficult; Liddell Diaries, 07/12/1948, KV/4/ 470, p.204

39. Liddell Diaries, 05/05/1948, KV/4/470, p.91

40. Gol, 'Continued retention of certain temporary posts in the various organisations under the Director Intelligence Bureau', MHA, Police-II, SECRET, 1950, 40/36/50, NAI

41. Liddell Diaries, 07/12/1948, KV/4/470, p.204

42. Liddell Diaries, 09/12/1948, KV/4/470, p. 205

43. Liddell Diaries, 07/12/1948, KV/4/470, p.204

44. Menon blamed Sanjeevi for misreporting about him to MI5 during his London visit. British intelligence was deeply sceptical of Menon's Communist sympathies and links (Nehru to Krishna Menon, 02/12/1948, SWJN, 2(8), 368-69); Paul McGarr, "A Serious Menace to Security': British Intelligence, V. K. Krishna Menon and the Indian High Commission in London, 1947-52', The Journal of Imperial and Commonwealth History, 38(3), 2010, 441-69.

45. Walton, Empire of Secrets, p.142.

46. Liddell Diaries, 23/05/1950, KV/4/472, p.91.

47. Mullik enjoyed Nehru's trust. So much so, that civilian officials termed it sycophancy and military officers viewed as perverse. K Sankaran Nair, $2^{\text {nd }}$ ed. Inside IB and RAW: The Rolling Stone that Gathered Moss (Delhi: Manas Publications, 2016), 98.

48. Nehru to Kher, 09/09/1952, SWJN, 2(19), July-Oct 1952, 632-4.

49. Ibid.

50. In 1957, Mullik told chief-MI5 Roger Hollis: 'In my talks and discussions [with MI5], I never felt that I was dealing with any organization that was not my own'. Andrew, Defence of the Realm, 444-5.

51. Bruce Vaughn, 'The Use and Abuse of Intelligence Services in India', Intelligence and National Security, 8(1), 1993, 1-22; B Raman, The Kaoboys of R\&AW: Down Memory Lane (New Delhi: Lancer Publishers, 2007$), 54-82$.

52. Nehru to Premier (Chief Minister), 05/02/1948, SWJN, 2(5), Jan-April 1948, p. 315.

53. An intelligence officer put it years later: '... in sharp contrast to their British predecessors; they [postindependence intelligence officers] were required to keep themselves completely away from politics. The sole political tendency expected, encouraged and rewarded was loyalty to the ruling party'. Yadav, Mission $R \& A W$, p. 24.

54. Nehru's condescension on a note by the IB's deputy director G K Handoo on how the public viewed Nehru in 1950 was apparent in a strong note he wrote to his private secretary: 'With all my admiration for the police, I still think I am better judge of certain matters than they are. I know perfectly well that the general reactions of people to me are good or bad, and I know more about the Indian people and crowds, both friendly and hostile, than probably any person in India'. Nehru to PPS, 11/07/1950, SWJN, 2(14:2), April-July 1950, 286-7. For more on Nehru's attitude towards intelligence see Paul McGarr, 'Tinker, Tailor, Soldier, Subversive: India, Pakistan, and the Cultural Politics of Cold War Intelligence', in L James and E Leake eds. Decolonization and the Cold War: Negotiating Independence (London: Bloomsbury, 2015), 285-302.

55. Nehru to Katju, 15/07/1952, SWJN, 2(18), April-July 1952, 296-7.

56. Nehru to Krishna Menon, 26/01/1949, SWJN, 2(9), Dec 1948-Feb1949, 391-3.

57. Nehru to Premiers [Chief Ministers], 05/02/1948, SWJN, 2(5), Jan-April 1948 p.315

58. In fairness, Nehru sided with the IB on this issue of a British national in Kalimpong. Nehru to Mountbatten, 18/09/1954, SWJN, 2(26), June -September 1954, 221-22.

59. Nehru to OPR Reddiar, 02/10/1948, SWJN, 2(7), July-October 1948, 274.

60. Nehru to B C Roy, 16/11/1950, SWJN, 2(15:1), Aug-Oct 1950, 341-2.

61. Nehru to Patel, 17/04/1949, SWJN, 2(1), Feb 1949-April 1949, 238-40.

62. Nehru to Patel, 01/12/1950, SWJN, 2(15:1), Aug-Oct 1950, 155-6.

63. Nehru to Sinha, 11/07/1950, SWJN, 2(14:2), April-July 1950, 287-8.

64. Nehru to Katju, 15/07/1952, SWJN, 2(18), April-July 1952, 296-7; According to R K Yadav, who joined R\&AW years after Nehru's death, there was a culture of political espionage encouraged by Congress leaders (if not Nehru himself) that made IB a politicized secret arm of the ruling party. Yadav, Mission R\&AW, 24-5.

65. Nehru to Rajaji, 11/09/1951, SWJN, 2(16:2), July-October 1951.

66. Nehru to Patel, 01/12/1950, SWJN, 2(15:1), Aug-Oct 1950, 155-6. 
67. Nehru to John Mathai, 22/02/1949, SWJN, 2(19), Feb-April 1949, 71.

68. McGarr, 'Tinker, Tailor, Soldier, Subversive', 285-302. In Burma, and Northeast India, Nehru viewed the presence of Christian missionaries as being part of the problem for fueling Naga, Karen, Kachin, and Chin separatism to the detriment of both Delhi and Rangoon. Kenton Clymer, A Delicate Relationship: The United States and Burma/Myanmar since 1945 (Ithaca, NY: Cornell University Press, 2015) 83-103; John Thomas, Evangelising the Nation: Religion and the Formation of Naga Political Identity (New Delhi: Routledge India, 2017) p.123

69. Raghavan, War and Peace in Modern India, p.25

70. India faced a humiliating military defeat vis-à-vis China in 1962 when the latter went to war over a disputed border. This was a strategic turning point in India's perception of China as well as itself. Nehru, who didn't expect Chinese aggression, became severely ill and died in 1964. For more on this war and the role of intelligence therein, see Ibid, 5-80; Bérénice Guyot-Réchard, Shadow States: India, China, and the Himalayas, 1910-1962 (Cambridge: Cambridge University Press, 2016); Paul McGarr, 'The long shadow of colonial cartography: Britain and the Sino-Indian war of 1962', Journal of Strategic Studies, 42 (5), 2019, 626-53.

71. Nehru to T T Krishnamachari, 02/11/1962, SWJN, 2(79), October-November 1962, p.76

72. Nehru to B C Roy, 17/04/1949, SWJN, 2(1), Feb-Apr 1949, p.224

73. Nehru to PPS, 01/05/1956, SWJN, 2(33), May-Jun 1956, p.243

74. Being suspicious of covert intelligence while maintaining an intimate relationship with intelligence chiefs, though paradoxical, was hardly unique to Nehru. A detailed comparative analysis of this issue is beyond the scope of this article, but many political leaders, such as British prime ministers Clement Attlee, Anthony Eden, Harold MacMillan, and Harold Wilson, denigrated the secret services, while maintaining a close relationship with intelligence chiefs. Attlee, for instance, established a channel with Percy Sillitoe, the Director-General of MI5 (1946-53), and bypassed the Home Secretary to receive direct intelligence briefings. Similarly, in the US, Richard Nixon, and more recently Donald Trump, have had equally paradoxical relations with the Directors of Central Intelligence. Richard J. Aldrich and Rory Cormac, The Black Door: Spies, Secret Intelligence, and British Prime Ministers (London: HarperCollins, 2016); Christopher R. Moran and Richard J. Aldrich, 'Trump and the CIA: Borrowing from Nixon's Playbook', Foreign Affairs, April 24, 2017. I would like to thank the anonymous reviewers for highlighting this aspect.

75. For an overview of India's coercive policing, paramilitary, and military measures, especially in conflict-ridden regions, see Subir Bhaumik, Troubled Periphery: Crisis of India's Northeast (New Delhi: Sage Publishers, 2009); Victoria Schofield, Kashmir in Conflict: India, Pakistan, and the Unending War (London: I B Tauris, 2010); K S Subramaniam, Political Violence and the Police in India (New Delhi: Sage Publishers, 2007)

76. Nehru on 'World Scenario and National Security', to DIG-P, New Delhi, 13/03/1956, SWJN, 2(32), Feb-Apr 1956, 489-98.

77. Till today, R\&AW's station in London is considered a 'Pakistan' posting. Nehru's focus on India's regional security issues was also reflected in how Mullik developed expertise within the IB, Nair, Inside IB and RAW, p.94

78. Ibid

79. In September 1961, the IB prepared a detailed paper for Nehru underlining the fact that the 'Chinese would like to come right up to their claim of 1960 wherever we were not in occupation. But where even a dozen men of ours are present, the Chinese have kept away'. This assessment of China's relatively benign response to Indian actions at the border proved inaccurate. D K Palit, War in High Himalayas: Indian Army in Crisis, 1962 (London: Hurst Publishers, 1992), 28-9; For an in-depth discussion on this issue see Raghavan, War and Peace in Modern India, 275-6; B N Mullik, My Years With Nehru: The Chinese Betrayal (Delhi: Allied Publishers, 1971), 314-5; Raje, 'Decisions in Crises', King's College London, 2020.

80. Walton, Empire of Secrets, 117-9. The Cambridge-five was a ring of Soviet spies in the United Kingdom that was active from the 1930s till late-1950s. They were Donald Maclean, Guy Burgess, Harold 'Kim' Philby, Anthony Blunt, and John Cairncross. Verne W Newton, The Cambridge Spies: The Untold Story of Maclean, Philby, and Burgess in America (New York: University Press of America, 1991); Ben Macintyre, A Spy Among Friends: Kim Philby and the Great Betrayal (London: Bloomsbury, 2014)

81. Ibid, p.232

82. 'Ghana Episode', Kao Papers, p.2

83. Singh, Power and Diplomacy, Introduction

84. Neera Chandhoke, 'Rooted Cosmopolitanism: Jawaharlal Nehru and Kwame Nkrumah', in Martin Odei Ajei ed. Disentangling Consciencism: Essays on Kwame Nkrumah's Philosophy (Maryland: Lexington Books, 2017), 303-14.

85. Gol, 'A Security Service for Ghana', Mullik to Nehru, 05/07/1957, JLN Papers, SECRET, 536/Pt.1, NAI, 1-5.

86. Ibid, p.5

87. 'Ghana Episode', Kao Papers, p.2

88. On colonial policing and intelligence see Georgina Sinclair, 'The Sharp End of the Intelligence Machine': The Rise of the Malayan Police Special Branch 1948-1955', Intelligence and National Security, 26 (4), 2011; Martin 
Thomas, Empires of Intelligence: Security Services and Colonial Disorder after 1914 (California: University of California Press, 2008); Philip Murphy, 'A Police State? The Nyasaland Emergency and Colonial Intelligence', Journal of South African Studies, 36 (4), 2010

89. Gol, 'A Security Service for Ghana', JLN Papers, p.4

90. Ibid, p.3

91. Ibid

92. Ibid, p.4

93. Scott Thompson, Ghana's Foreign Policy, 1957-1966: Diplomacy, Ideology, and the New State (New Jersey: Princeton University Press, 1969), 414-40.

94. Gol, 'A Security Service for Ghana', JLN Papers, p.4

95. Richard Rathbone, 'Police Intelligence in Ghana in the late 1940s and 1950s', The Journal of Imperial and Commonwealth History, 21(3), 1993, 107-28.

96. Gol, 'A Security Service for Ghana', JLN Papers, 3.

97. Ibid

98. Each province in Ghana was divided into five or six districts controlled by a Superintendent of Police, and each district had five or six police stations, each in charge of an Inspector. Ibid, p.1

99. Francis D Baoteng and Isaac N. Darko, 'Our Past: The Effect of Colonialism on Policing in Ghana', International Journal of Police Science and Management, 18(1), (2016), 13-20.

100. Ibid, 2.

101. Ibid, 3-4.

102. Walton, Empire of Secrets, p.229

103. The Security Service, Personal Files, Kwame Nkrumah, KV2/1851, UKNA, July 1953

104. Ibid, Accra to London, May 30, 1953. Between 1952-7, London was worried about communist influence on Nkrumah, especially of George Padmore, a pan-Africanist and a member of the Communist Party. The Security Service, Personal Files, Kwame Nkrumah, KV2/1850, UKNA, 1952

105. 'Ghana Episode', Kao Papers, 7-8.

106. There is no evidence as such that the FSRB itself turned against Nkrumah. Patrick P. Obuobi, 'Evaluation Ghana's Intelligence Oversight Regime', International Journal of Intelligence and Counterintelligence, 31(2), 2018, p.314

107. Yadav, Mission R\&AW, p.28

108. Gol, 'Note on the organisation of the Ghana External Intelligence Service', Nehru to Nkrumah, 28/11/1957, JLN Papers, 2391-PMH/57, 23-4.

109. Ibid

110. Ibid

111. Ibid

112. 'Ghana Episode', Kao Papers, p.4

113. Kao took two other IB officers with him Lal Kripalini as his intelligence assistant, and Handa as his private secretary. Both of them stayed back in Accra after Kao's departure and continued in their position with Nair. There is no available written or oral testimony of these officers and their experience in Ghana, which lasted longer than both Kao and Nair. Nair, Inside IB and RAW, p.125

114. A. A. Golds, UK High Commission Karachi to Commonwealth Relations Office, 'Reports on Pakistan's attitude towards Africa, particularly Nigeria', 22/09/1960, FO 371/146500, UKNA.

115. Ibid

116. Nair, Inside IB and RAW, p.125

117. 'Ghana Episode', Kao Papers, 1-20; Nair Inside IB and RAW, 123-49.

118. Yadav, Mission R\&AW, 95-100; Nitin A Gokhale, R N Kao: Gentleman Spymaster (New Delhi: Bloomsbury, 2019), 82-100.

119. Singh, Power and Diplomacy, Introduction and Chapter 1

120. 'Ghana Episode', Kao Papers, p.5

121. Nair, Inside IB and RAW, p.124

122. Ibid

123. 'Ghana Episode', Kao Papers, p.17

124. Ibid

125. Ibid, 21-2.

126. Ibid; 'Ghana Episode', Kao Papers, p.9

127. 'Ghana Episode', Kao Papers, p.24

128. Nair, Inside IB and RAW, 127-8.

129. Ibid, 143-4.

130. Years later the CIA assessed Forjoe to be a 'moderate' who was 'suspicious of the Communist bloc' and was likely to monitor undesirable 'Libyan activity in Ghana'. CIA, 'Ghana: Rawlings Takes Charge Again', SECRET, https://www.cia.gov/library/readingroom/docs/CIA-RDP84B00049R000200400093-9.pdf 
For more on Forjoe see 'Rawlings pays respects to former National Security Chief', GhanaWeb, 09/08/2013; According to one of his colleagues, Forjoe played a role in tempering Nkrumah's ambitions by following the rule of law, but with unstinting loyalty. K B Asante, 'Existing rules can deal with indiscipline', Graphic Online, 05/08/2013

131. 'Ghana Episode', Kao Papers, p.7

132. Ibid, p.18

133. Ibid, on the Kashmir Princess see Steve Tsang, 'Target Zhou Enlai: The 'Kashmir Princes' Incident of 1955', The China Quarterly, 139, September 1994, 766-82.

134. 'Ghana Episode', Kao Papers, 7.

135. Nair, Inside IB and RAW, 133-4.

136. On Forjoe's training in Israel, 'Rawlings pays respects to former National Security Chief', GhanaWeb, 09/ 08/2013.

137. Nicolas Blarel, The Evolution of India's Israel Policy: Continuity, Change, and Compromise since 1922 (New Delhi: Oxford University Press, 2015), 177-8.

138. Nair, Inside IB and RAW, 133-4.

139. 'Ghana Episode', Kao Papers, 5.

140. Ibid

141. Nair, Inside IB and RAW, 141-2.

142. Nehru to Nkrumah, 20/04/1957, SWJN, 2(37), Feb-April 1957, 536-7.

143. Thompson, Ghana's Foreign Policy, 1957-1966, 57-118.

144. 'Ghana Episode', Kao Papers, 21.

145. Ibid.

146. Government of Ghana, 'Bureau of National Security', Chief Secretary's Office, SECRET, 08/10/1960, File RG2/4/ 26, Public Records and Archives Administration Department (PRAAD), Accra.

147. Gol, Ghana: Visit of the Prime Minister of Ghana Dr. Kwame Nkrumah to India, MEA, 19(45)-AFR, 1957, NAI.

148. Gol, Kapur to Desai, 17/09/1958, SECRET, 1957, 19(45)-AFR, NAI

149. Christopher Andrew and Vasili Mitrokhin, The World was Going Our Way: The KGB and the Battler for the Third World (New York: Basic Books, 2005), 434-5. For more on Cold War intelligence competition in Africa see James R Brennan, 'The Secret Lives of Dennis Phombeah: Decolonization, the Cold War, and African Political Intelligence, 1953-1974', The International History Review, June 2020.

150. Ibid; Natalia Telepneva, 'Saving Ghana's Revolution: The Demise of Kwame Nkrumah and the Evolution of Soviet Policy in Africa, 1966-1972', Journal of Cold War Studies, 204 (4), Fall 2018, 4-25.

151. Walton, Empire of Secrets, p.232; Seymour M Hersh, 'C.I.A. said to Have Aided Plotters Who Overthrew Nkrumah in Ghana', New York Times, 09/05/1978; on Soviet exit see Andrew and Mitrokhin, The World was Going Our Way, 436-7.

152. 'Ghana Episode', Kao Papers, p.24

153. Walton, Empire of Secrets, p.235

154. Yadav, Mission R\&AW, p.28

155. Ibid

156. The DIBs at that point in time tried to scuttle the creation of a separate foreign intelligence agency and refused to transfer officers working on IB's foreign desk to Kao. Interventions by Gandhi's Principal Secretary, P N Haksar, and the Foreign Secretary T N Kaul, assuaged these bureaucratic rivalries. Yadav, Mission $R \& A W, 28-9$.

157. This raises the question why Indira Gandhi's politicization of India's intelligence services to support the state of 'Emergency' (1975-77) -an authoritarian move- was allowed to occur, if the checks and balances of India's democracy had a restraining effect on Nehru? There are three reasons for this. One, Indira Gandhi's rise to power within the Congress was tumultuous. Unlike Nehru, who worked with regional interlocutors -known as the 'Syndicate'- Gandhi developed a populist, anti-Syndicate, streak and politically undermining regional party leaders. Such a populist turn removed the intra-party checks-and-balance for Gandhi by early 1970s. Two, the R\&AW was created by a prime-ministerial ordinance akin to the FSRB in Ghana and has been directly -and only- answerable to the prime minister ever since. By mid-1970s, Gandhi's advisory circle got limited to a select set of bureaucrats and family members, affording her tremendous power. Three, unlike her father, Gandhi was more invested in India's domestic and regional security instead of being a global peacemaker. India's defeat in 1962 to China played a big role in this shift. The 'Emergency' was the manifestation of cumulative insecurities as she felt threatened from enemies from both within and outside. Christophe Jaffrelot and Pratinav Anil, India's First Dictatorship: The Emergency, 1975-1977 (London: Hurst Publishers, 2020). Some Indian intelligence officers from both R\&AW and IB refute that their institutions were involved in deciding upon or enabling government excesses during the Emergency: Raman, The Kaoboys of R\&AW, p. 49-53 and T V Rajeswar, India: The Crucial Years (New Delhi: HarperCollins, 2015). Others 
acknowledge the misuse of intelligence but put the blame on her son Sanjay, rather than on Indira Gandhi herself. Nair, Inside IB and RAW, 168-72.

158. Obuobi, 'Evaluation Ghana's Intelligence Oversight Regime', p.313

159. Full text of The Intelligence Services (Powers and Regulations) Bill, 2011: https://www.thehindu.com/ multimedia/archive/00852/THE_INTELLIGENCE_SE_852812a.pdf

160. Raje, 'Decisions in Crises', 2020, 61-90.

\section{Disclosure statement}

No potential conflict of interest was reported by the author(s).

\section{Notes on contributor}

Avinash Paliwal is Senior Lecturer in International Relations and Deputy Director of the South Asia Institute at SOAS University of London. This article benefitted from excellent feedback by the two anonymous reviewers, Martin Bayly, Pallavi Raghavan, Kate Sullivan de Estrada, P C Dheeraj, Johann Chacko, Vineet Thakur, Patrick Obuobi, and Aryaman Bhatnagar. In New Delhi, Asmita Mahajan and Paridhi Gupta offered excellent research assistance at the archives. The author thanks them all. 